\title{
固有鼻腔内逆生歯牙の一症例
}

澤田 達哉・八木沢幹夫・酒井 正喜

岡本 啓孝・大森 环也・西村 忠郎

\section{A Case of Abnormal Dental Eruption in the Nasal Cavity}

Tatsuya Sawada, Mikio Yagisawa, Masaki Sakai, Hirotaka Okamoto, Takuya Ohmori and Tadao Nishimura

(Fujita Health University The Second Affiliated Hospital)

A boy, aged 10, showed an abnormal eruption of an incisor in the right nasal cavity. Including our case, there were 126 cases, involving 131 teeth, of dental abnormalities reported in the literature of this country.

Statistically, there were 8 men and 5 women, more cases involving supernumerary teeth than normal teeth, more teeth. Involving permanent than deciduous teeth, more involving the incisors than canines and more in the left nare than the right.

Key words: abnormal eruption, nasal cavity, supernumerary tooth

緒言

上顎骨の構造上，耳鼻咽喉科疾患に歯牙が関 与することは稀ではない，歯牙が歯列弓上の正 規の位置に萌出せず，固有鼻腔内または上顎洞 に萌出する，いわゆる逆生歯牙については，石 井1)によると，1754年に Albinus が最初に報告 したとされ，次いで1797年に文豪 Goethe がス イス紀行中に記載している。本邦では1901年に 金杉2) が固有鼻腔内逆生歯牙の 1 例を報告した のが最初である. 固有鼻腔内逆生歯牙について は必ずしも珍しいものではなく，これまでも多 数の報告がされているが，日常の診療で遭遇す る機会は比較的稀である。今回我々は，小眼球 症, 先天性後鼻孔閉鎖症の小児に発生した固有 鼻腔内逆生歯牙の 1 例を経験したので若干の文 献的考察を加光て報告する。

\author{
症例 \\ 患者：10歳, 男児. \\ 主訴 : 右頓部腫脹. \\ 既往歴: 生下時体重は $2508 \mathrm{~g}$, 正常分婏, \\ 生下時より先天性両後鼻孔閉鎖症, 左小眼球症 \\ が存在した. \\ 昭和57年 4 月；左眼球沃褧摘出術. \\ 昭和61年 10 月 ; 左下眼瞼形成術. \\ 昭和62年10月；右後鼻孔閉鎖症開放術. \\ 昭和63年 1 月; 両後鼻孔閉鎖症開放術. \\ 昭和63年 7 月; 両後鼻孔閉鎖症開放術. \\ 家族歴: 家族に先天的疾患, その他の特記す \\ べき疾患は認められない。 \\ 現病歴: 平成 2 年 7 月頃感冒症状を呈し, 右 \\ 頓部痛出現するも自然軽快した。平成 3 年 5 月 \\ 右歯痛および右煩部痛のため近医歯科受診, そ
}


の後軽快した。平成 4 年 1 月頃より右頓部腫脹 出現，次第に増大傾向にあるため同年 3 月 28 日 当科受診，右上顎洞試験開洞術目的に同年 4 月 4 日当科入院となった。

全身所見：特記すべきものは認められなかっ た。

局所所見：入院時右頓部腫脹あり(図 1 )右鼻 腔内は下甲介が外側方上り圧排され下鼻道粘膜 の一部は腫脹していた。

検査所見: 末梢血, 生化学, 尿検査, 心電図, 胸部X線等では異常を認めず，血清梅毒反応は 陰性であった。

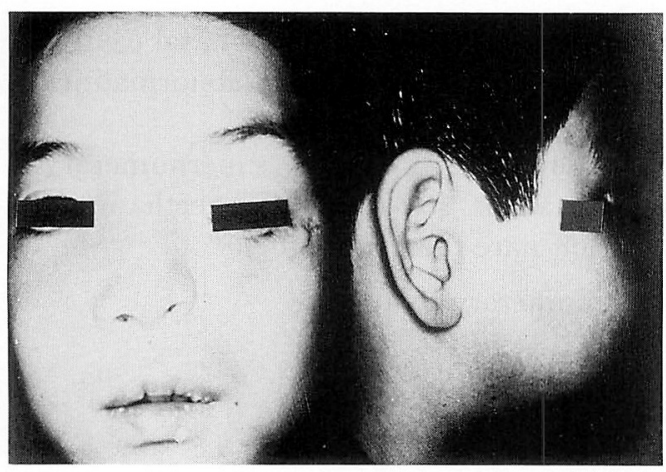

図 1 症例

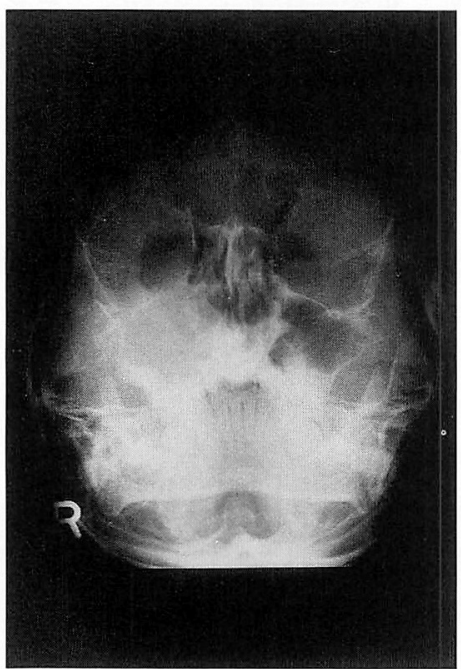

図 2 入院時の顔面単純 $\mathrm{X}$ 線写真
$\mathrm{X}$ 線所見：入院時の顔面単純 $\mathrm{X}$ 線写真では (図 2 )，右鼻腔内抢上び右上㴿洞に，異常陰影 が認められた. 入院時の副鼻腔単純 CT では(図 3 ), 右上顎洞は拡大し内部は均一な低吸収域 で充満していた。壁は菲薄化し，上壁掞よび下 壁には骨破懐がみられた。腫瘍も否定できず右 上顎洞試験開洞術を施行した。

手術所見：術中鼻内所見では(図 4)，下鼻道 側壁は腫脹し下甲介は正中に圧排され腫脹して いた. 局所麻酔下に右歯敬部切開を加光骨壁を 削開し洞内容を吸引すると淡紅黄色で混濁した ゲル状の内容が認められ，洞粘膜は薄く囊胞様

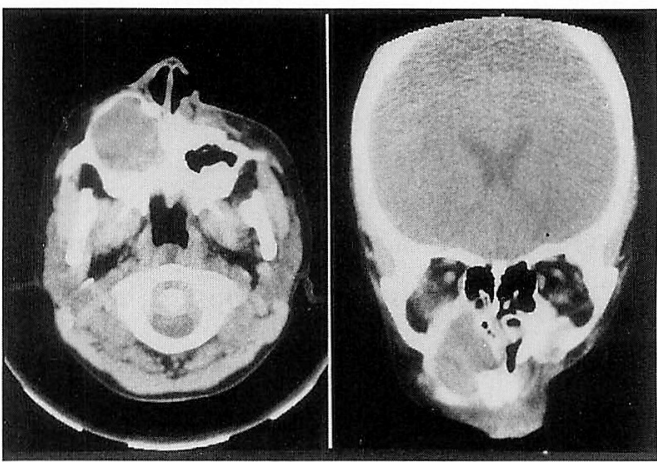

図 3 入院時の副鼻腔単純 CT

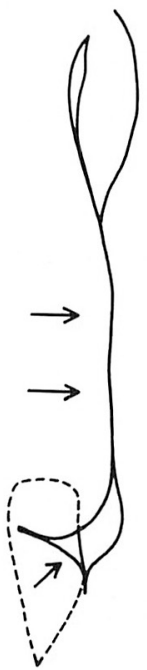

図 4 術中鼻内所見 
であった．下鼻道側壁の腫脹した粘膜を除去す ると，逆生歯牙を認めこれを摘出した．摘出し た歯牙は切歯状であった(図 5 ).

病理所見：摘出した歯牙は，歯髄扣上び象牙 質が認められ病理組織学的にも柬牙であると診 断された(図6).

治療経過：術後経過は良好で，手術後 2 週間 の副鼻腔単純 CT では(図 7 ), 右上顎洞の低吸 収域は消失し，良好に含気化していた。自覚症 状も消失して和り平成 4 年 4 月 25 日退院となっ た。

診断：手術後 1 力月のパノラマX線写真では

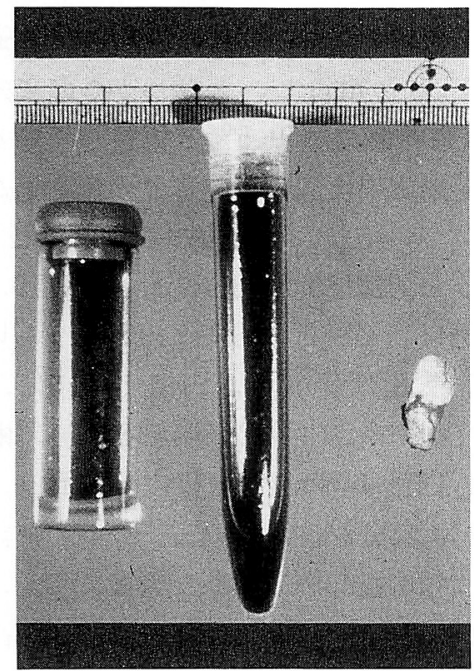

図 5 摘出標本および洞内容

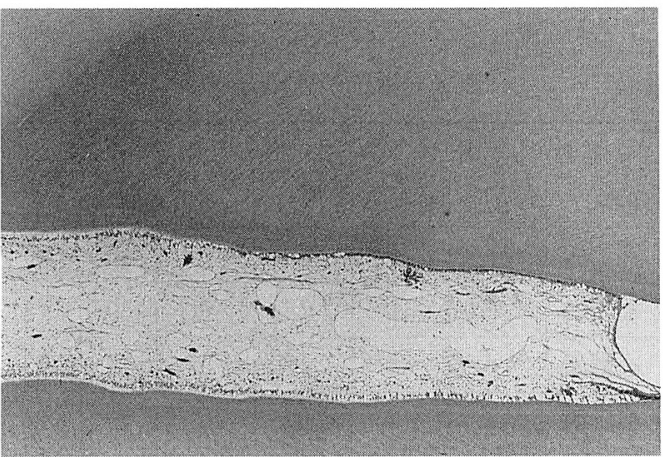

図 6 病理組織 $($ H.E. 染色 $\times 40)$
(図 8 ), 乳歯は $\mathrm{D} \mathrm{C}|\cdot \mathrm{E}| \cdot[\mathrm{E} \cdot \mid \mathrm{E}$ が，永久

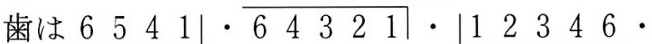
122346 が萌出, 歯列の異常が著明で，3 は5 の根尖部に埋没歯として存在するが, 治 療の必要性を認めなかった. 7$\rfloor \cdot \overline{75} \cdot\lfloor 57$

・ 57 は萌出していなかった。 今回摘出した 逆生歯牙はこれらの所見招よび摘出した歯牙の 形態からも右側切歯と考光た。

考案

本邦に扣いて発表された固有鼻腔内逆生歯牙 症例は1901年に金杉2)が 1 例を報告したのに始 まり，著者らが渉弾し得た範囲では，本報告例 を含めて126例131歯であった。

固有鼻腔内逆生歯牙症例につき，その定義な らび臨床像を以下に述べる。

1. 逆生歯牙の定義について

正常な歯牙は歯列内のそれぞれの定まった位

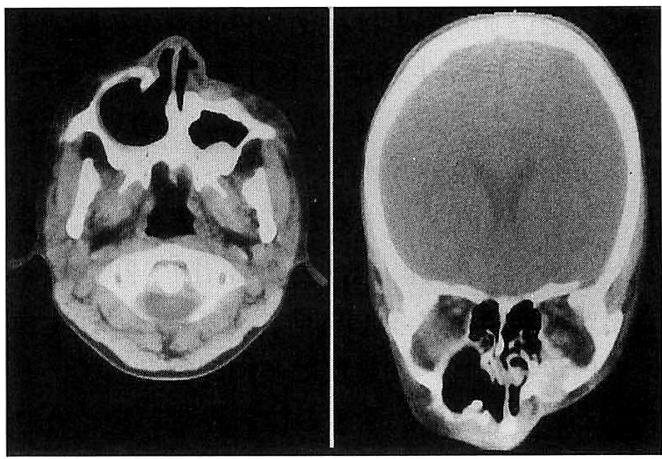

図 7 手術後 2 週間の副鼻腔単純 CT

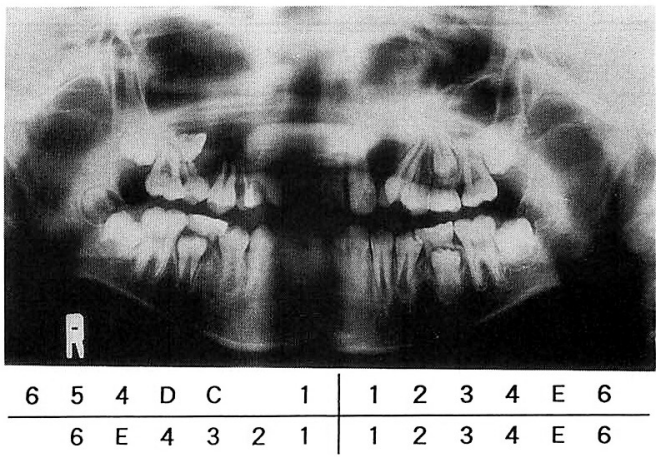

図 8 手術後 1 カ月のパノラマX線写真 
置に萌出するが，時として歯列からはずれた位 置に萌出することがある. この状態を歯牙の転 位と呼び，その中で歯冠が正常の萌出方向とは 逆の方向に向かっているものを逆生歯牙と呼ぶ. 萌出形態に関しては，歯冠が固有鼻腔内または 上顎洞内に完全に萌出している場合と，歯冠が 粘膜下にあり，上顎骨内に埋伏している場合と がある。また歯牙の種類に関していえば，本症 例のように正常歯式内の歯牙が逆生する場合と， 歯式外に発生した過剩歯が逆生する場合とがあ る.

\section{2. 性 別}

男女比は, 古市ら ${ }^{3)}$ は $1.8: 1$, 河合 $5^{4)}$ は $1.63: 1$, 中西ら5) は $1.9: 1$, 天野ら ${ }^{6)}$ は 1.18 : 1 と報告しているが，今回の集計では，1.6:1 であった（表 1)。なぜ男性に多いのかは不明で ある。

\section{3 . 年 齢}

ここでいら年齢とは症例の受診時の年蹂であ り逆生歯牙の発生時期は不明である. 古市ら ${ }^{3)}$ は10２0歳代が最も多く62.8\%，河合ら ${ }^{4)}$ は20 歳以下が70.8\%, 中西ら5) は10 20歳代が58.8 $\%$, 天野ら ${ }^{6)}$ は20歳未満が $67.5 \%$ と報告してい るが，今回の集計でも(表 1 )，10 20歳代が $52.4 \%$ と若年者に多く発見されている. 逆生歯 牙の出現率が $10 \sim 20$ 歳代に多い理由として, 石 井1) は第 2 生歯期に歯牙の位置異常が起こりや

表 1 年齢と性別

\begin{tabular}{l|c|c|c|c}
\hline \hline \multicolumn{1}{c|}{ 年㱓 } & 男性 & 女性 & 不明 & 合計 $(\%)$ \\
\hline 10 歳未满 & 18 & 14 & 0 & $32(25.4)$ \\
$10 \sim 19$ & 26 & 17 & 0 & $43(34.1)$ \\
$20 \sim 29$ & 17 & 4 & 2 & $23(18.3)$ \\
$30 \sim 39$ & 4 & 2 & 0 & $6(4.8)$ \\
$40 \sim 49$ & 5 & 2 & 0 & $7(5.6)$ \\
$50 \sim 59$ & 4 & 5 & 0 & $9(7.1)$ \\
$60 \sim$ & 1 & 3 & 0 & $4(3.2)$ \\
不 明 & 0 & 0 & 2 & $2(1.5)$ \\
\hline 合計 & 75 & 47 & 4 & 126 \\
(\%) & $(59.5)$ & $(37.3)$ & $(3.2)$ &
\end{tabular}

すいためであると述べている．しかし古市ら ${ }^{3)}$ はこの年齡になると鼻閉や鼻内異物感などの症 状を病識として自覚してこれを訴えるようにな るために受診頻度も高くなり，したがって歯牙 異常が発見されやすくなるためと述べている.

\section{4. 歯牙の種類と形態}

今回集計した固有鼻腔内逆生歯牙131歯につ いて，種類と形態を分類すると表 2 のようにな る.

種類については正常歯が44歯33.6\%, 過剰歯 が63歯48.1\%であった。これに対して石井1は 鼻腔内出現67例中, 正常歯26例 $38.8 \%$, 過剩歯 29 例 $43.3 \%$ と報告し, 古市ら ${ }^{3)}$ は93例中, 正常 歯40例 $43.0 \%$, 過剩歯41例 $44.1 \%$ と報告し, 中 西ら5) は102例中, 正常歯41例 $40.2 \%$, 過剩歯 48 例 $47.1 \%$ と報告し, 天野ら ${ }^{6)}$ は正常歯 3 例 $8.1 \%$ ，過剩歯 22 例 $59.5 \%$ と報告している. 正 常歯之過剩歯の出現率が同程度の報告例が多い。

形態については，正常歯においては石井1)は 26例の5ち切歯18例 $69.3 \%$, 犬歯 5 例 $19.2 \%$, 臼歯 3 例 $11.5 \%$, 古市ら ${ }^{3)}$ は40例のうち切歯 20 例 $50 \%$, 犬歯16例 $40 \%$ ，臼歯 4 例 $10 \%$, 中西 ら5) は41例のうち切歯20例 $48.8 \%$, 犬歯17例 $41.4 \%$, 臼歯 4 例 $9.8 \%$ と報告しており, 切歯 と犬歯が大部分を占めている. 今回の集計でも, 44例の5ち切歯23例 $52.3 \%$, 犬歯17例 $38.6 \%$, 臼歯 4 例 $9.1 \%$ と切歯と犬歯が大部分を占めて いる.

過剩歯においては古市ら 3 は32例のらち切歯

表 2 歯牙の種類と形態

\begin{tabular}{|c|c|c|c|c|c|c|}
\hline 種類 & $\begin{array}{l}\text { 切歯 } \\
\text { 执よ场 } \\
\text { 切歯状 }\end{array}$ & $\begin{array}{l}\text { 犬歯 } \\
\text { 尔よ゙点 } \\
\text { 犬状 }\end{array}$ & 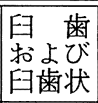 & その他 & 不明 & 合計 \\
\hline 乳 歯 & 17 & 16 & 3 & 0 & 0 & 36 \\
\hline 永久歯 & 6 & 1 & 1 & 0 & 0 & 8 \\
\hline 過剰歯 & 6 & 32 & 1 & 5 & 19 & 63 \\
\hline 不 明 & 2 & 3 & 0 & 0 & 19 & 24 \\
\hline 合 計 & 31 & 52 & 5 & 5 & 38 & 131 \\
\hline
\end{tabular}


状 5 例 $15.6 \%$, 犬歯状22例 $68.7 \%$, 中西ら5) は 48例のらち切歯状 5 例 $10.4 \%$, 犬歯状 26 例 54.2 $\%$ ， 犬歯状過剰歯が過半数を占めている. 今 回の集計でも，形態を記載してある44例につい てみると，切歯状 6 例 $13.6 \%$ ， 犬歯状32例 72.7 $\%$ ，臼歯状 1 例 $2.3 \%$ と犬歯状過剩歯が大多数 を占めている.

\section{5 . 左右別}

石井1) は上顎歯牙の位置異常症例のうち左右 別の記載のあるもの233例の集計をし，左側は 108例 $46.4 \%$, 右側は 112 例 $48.1 \%$, 正中部は 2 例 $0.9 \%$, 両側は 11 例 $4.7 \%$ であり, 左右差はな いと報告している。しかしながら，古市ら゙は 固有鼻腔内逆生歯牙79例のうち左側は 48 例 60.8 $\%$, 右側は26例 $32.9 \%$, 正中部は 5 例 $6.3 \%$, 中西ら ${ }^{5)}$ は88例のうち左側は54例 $61.4 \%$, 右側 は29例 $33.0 \%$, 正中部は 5 例 $5.7 \%$, 天野ら 6 は32例のらち左側は 21 例 $65.6 \%$ ，右側は10例 $31.3 \%$, 正中部は 1 例 $3.1 \%$ と左側に高率であ ると報告して拉り，従来より先天奇形は左側に 多いといわれているが，今回の集計でも左右別 の記載のあるもの112例のうち左側は69歯61.6 $\%$, 右側は 37 歯 $33.0 \%$, 正中部は 6 歯 $5.4 \%$ と 約 2 倍左側に多くみられた(表 3 ).

\section{6 . 発生原因}

逆生歯牙の発生原因については鈴木7) が, Salter, Seifert，村上 ${ }^{8)}$ の文献をもとにして次 のように要約している.

1）歯胚が翻転する場合

（胎生時の口蓋破裂が閉鎖する前に歯胚 が翻転する場合.

(b最初から不正位置にある歯胚による場 合.

2 ）過剩歯胚による場合

（a口蓋破裂閉鎖前に鼻腔などに侵入する

表 3 左右別

\begin{tabular}{c|c|c|c|c|c|c}
\hline \hline & 左側 & 右側 & 正中部 & 両側 & 不明 & 合計 \\
\hline 歯数 & 69 & 37 & 6 & 0 & 19 & 131
\end{tabular}

場合.

(b最初から不正位置にある歯胚による場 合.

(C口腔内に発育すべき場所がなくて他の 場所に発生する場合.

3）切歯骨の転位による場合

4）乳歯が残存する場合これに代るべき永久 歯の発生する場所がなく他の場所に発生 する場合

5 ) 歯根が異常に長く発育して鼻腔・副鼻腔 などに突出する場合

6 ）鼻底および上顎骨が外傷あるいは梅毒な ぞのために破壊されて歯肧が移動する場 合

7 ）解剖学的奇形の局所現象としてくる場合

8 ）歯牙と歯槽との平均発育の欠ける場合, ことに歯槽の発育良好な時にその方向を 鼻腔・副鼻腔などに転じて逆生する場合

1）から 4) までが上顩骨において歯冠を上 方に歯根を下方に向けた真の逆生歯牙であると している.

本症例に执いては，まず先天性両後鼻孔閉鎖 症があり，また左顔面の低形成が認められ，左 右の上顎洞と顎の発育に差が生じたこと，また， 咬合等の不整により，顎全体が発育不良となっ たこと，これらにより歯列の異常を来したこと， などが逆生歯牙発生の原因であろらと考劣た。 また下甲介の圧排により自然孔を閉鎖し上靧哄 胞が発生したと考えた．今回の症例では，7）

8 ）等が複雑に絡み合って逆生歯牙が発生した ものと考光た.

外傷に関しては石井9) は幼児期の上顎部の外 傷を重視して報告しているが，今回の集計では 126例のらち 4 例 $3.2 \%$ にすぎなかった．梅毒に 関しては久保10)，今村11) が重視し，これを報告 しているが，今回の集計では 3 例 $2.4 \%$ にすぎ なかった。また，古市ら ${ }^{3)}$ は奇形に関しては， 兔唇口蓋裂の発生機序を詳細に検討して，逆生 歯牙は歯胚が切歯間縫合の閉鎖前に転位を起こ すため生ずると述べ，逆生歯牙は先天性，奇形 
性に成立するものであって，鬼唇口蓋裂と同じ 範疇に入るものであると結論している．今回の 集計では兔唇口蓋裂を合併したものが20例15.9 \%と高率に認められている。

7 . 自覚症状

鼻閉, 鼻出血が最も多く, 鼻漏, 頭重感, 違 和感，嗅覚障害などが挙げられるが312)，無症 状で偶然の機会に発見される場合もあり12)，逆 生歯牙に特有の症状ではない。また Smith ら 12)がまとめた報告によれば，軽度の顔面痛， 微熱などの症状も現われることもあると報告し ている.

\section{8. 治 療}

逆生歯牙の場合は手術的にこれを摘出する以 外に方法はない。

\section{結語}

固有鼻腔内の逆生歯牙の一症例を経験したの で本邦での報告例をまとめ，本症例と本疾患に つきその詳細を報告した。摘出した歯牙状のも のは右上顎側切歯であると考光た．本症例は先 天性両後鼻孔閉鎖症があり，左右の上顎洞と顎 の発育に差が生じ歯列の異常を来した。これが 逆生歯牙の発生の一因となったと考えた。この ような奇形が存在する場合, 逆生歯牙の発生を 防止するためには早期に根治的手術を施行し, 鼻腔，洞和よび上顎骨の発育が良好になるよう に心がけるべきであると考えた。

本疾患は男性に多発，過剩歯の比率が多く， 正常歯では切歯, 犬歯とも注注同率であるが過 剰歯では犬歯状のものが多い。また，左側に多 発している，鬼唇口蓋裂を合併したものが高率 にみられる。

なお本論文の要旨は第69回日本耳鼻咽喉科学会東 海地方部会連合講演会に扮いて発表した.
文献

1）石井 正：上顎歯牙，位置異常二関スル研究 （鼻腔卜歯牙卜ノ臨床的関係二就テノ研究 第 二部)。大日耳鼻 $33: 666 \sim 698,1927$.

2）金杉英五郎：鼻腔内歯牙発生ノ一例(歯牙過贅) 並ニ「デモンストラチオン」. 大日耳鼻 $7: 73$ $\sim 81,1901$.

3）古市暢夫, 山本和久, 大藤周彦, 他 : 固有鼻腔 内逆生歯牙症例 一その 2 症例と文献的考察一. 耳喉 $47:$ 559 565, 1975.

4）河合清隆, 岩波清孝, 徳川博武, 他 : 固有鼻腔 内逆生過剩歯牙の 1 症例. 医療 $32: 214 \sim 216$, 1978.

5）中西 弘, 榎本雅夫, 寒川高男, 他 : 鼻腔内逆 生歯牙の 1 例. 和歌山医学 $38: 521 \sim 525,1987$.

6）天野孝志, 生駒尚秋：鼻腔内逆生歯の 1 例とそ の文献的考察. 耳鼻 $36: 1126 \sim 1131,1990$.

7）鈴木盛明：上顎洞内過剩逆生歯牙の 1 例. 耳鼻 臨床 $51: 63 \sim 65,1958$.

8）村上正徳：歯牙逆生二就テ.十全会誌 $23: 9$, 1918.

9）石井 正：歯牙逆生及び埋伏の原因論併せて濾 胞性歯牙整腫の発生に就て. 日本之歯界 101 : $1 \sim 35,1928$.

10）久保猪之吉 : 鼻内逆生歯牙患者供覧. 大日耳鼻 $29: 524,1923$.

11）今村政子：乳児逆生歯牙症例. 大日耳鼻 49： 587, 1943.

12) Smith RA, Gordon NC and De Luchi SF : Intranasal teeth. Oral Surg $7: 120 \sim 122,1979$.

$\left(\begin{array}{l}\text { 別刷請求先 : 澤田達哉 } \\ \text { †454 名古屋市中川区尾頭橋3-6-10 } \\ \text { 藤田保健衛生大学第 } 2 \text { 教育病院 } \\ \text { 耳鼻咽喉科学教室 }\end{array}\right)$

